\title{
Becoming a Scientist: Gender and Knowledge in Eighteenth- Century Italy
}

\section{Paula Findlen}

Department of History, Stanford University, California

\section{Argument}

This essay explores how and why women involved themselves in the sciences in eighteenthcentury Italy. Using the case study of Diamante Medaglia Faini, a poet who attempted to become a mathematician, it argues that the image of the woman natural philosopher was shaped by the visible presence of woman in scientific institutions in the mid-eighteenth century and by the tradition of popular scientific writing, best embodied in the works of Bernard le Bovier de Fontenelle and Francesco Algarotti, that made the woman natural philosopher an important literary protagonist. Becoming a scientist, in other words, was both a reality and a fiction. The tensions between these two different images shaped the terrain in which women pursued science.

And you ask me, who was truly the Marchesa of my dialogues? I respond: A grandniece of Fontenelle, or perhaps one of my own daughters, made by me just as I would have liked her, with a lively and sophisticated mind, very curious, and able to listen carefully. But if the Marchesa of my dialogues is imaginary, the one to whose judgment this work is now submitted, is not.

- Francesco Algarotti, 1763 (Algarotti 1791-94, 10:173)

Towards the end of the seventeenth century, a new scientific persona entered the consciousness of natural philosophers and their nascent public. It was not the brainchild of someone engaged deeply in the study of nature, but the offspring of a Parisian literary jack-of-all-trades and salonnièr, Bernard le Bovier de Fontenelle, later to be appointed perpetual secretary of the Paris Academy of Sciences because of his skill in communicating scientific knowledge. In his Conversations on the Plurality of Worlds (1686), the twenty-nine year old Fontenelle wielded his ferociously witty pen to create a new image of the natural philosopher. No longer a man of the university, a scholastic master surrounded by male disciples, Fontenelle's philosopher was a 
charming seducer of women, a wit who made science comprehensible by cultural analogy. ${ }^{1}$ His knowledge was no social liability that removed him from ordinary conversation, but the very reason that he held the attention of an aristocratic Marquise for several days and nights, as he educated her in the mysteries of the postCopernican, Cartesian universe.

Fontenelle's popular Conversations, which went into ten French editions in his own lifetime and produced multiple translations in various European languages, described not just one but two scientific personae. He not only sketched a portrait of the modern philosopher, but also created a template of the scientific woman in the form of the Marquise. It was the interaction between these two figures that made his Conversations such a radical departure from previous efforts to popularize scientific knowledge. While dialogue already had been used to good effect in the works of Galileo, who had modernized the idea of the Platonic dialogue as a vehicle for debating scientific ideas, no previous writer had considered a woman to be an appropriate participant in a fictional discussion of natural philosophy. Fontenelle was the first to imagine that this dynamic would appeal to a heterogeneous audience for science. The Marquise was his tabula rasa whose head he filled with ideas, a woman who knew nothing of science and wanted to know virtually everything. His philosopher was a man eager to impart knowledge wherever he found his audience - leaving the opera, putting down a novel, or enjoying a moonlit walk after dinner in the countryside. He made scholars out of those who did not possess the kind of education that would make them scholarly on their own.

In contrast to the flirtatious philosopher, who saw the pleasures of the mind as a prelude to the pleasures of the flesh, Fontenelle's Marquise sought only knowledge. At many points in the Conversations, she made it clear that the only part of her willing to be seduced by the opposite sex was her mind. Fontenelle's philosopher may have been playful and charming, a man about town, but his Marquise was deadly earnest. She was there "to encourage women through the example of a woman." Fontenelle was quick to tell his female readers that the abilities of his imaginary woman philosopher did not exceed their own capacity to learn. Quite the opposite. "Why would any woman," he wrote, "accept inferiority to this imaginary Marquise?" (Fontenelle 1990, 4). Fontenelle's literary rendition of the life of science in the late seventeenth century served two purposes: it demonstrated the possibilities of a natural philosophy removed from learned academies and universities, and it argued that some form of scientific knowledge was hardly beyond the grasp of most women. The Marquise was more than just a literary fiction but a model, sketched from the ingredients of French salon life, for other women to emulate and surpass (Lougee 1976).

\footnotetext{
${ }^{1}$ In essence, Fontenelle's philosopher was the heir to the witty court philosophers who emerged in the midseventeenth century as best able to explain natural philosophy to a general audience (see Biagioli 1993).
} 
Fontenelle's Conversations was an ideal portrait of the life of two minds created for the entertainment of French society. It drew upon social ingredients that were readily found in his world, creating a distinctive image of male and female natural philosophers who came together through the mutual seduction of knowledge. In the late seventeenth century, it had few, if any, imitators. By the mid-eighteenth century, however, dozens of books described in one way or another as pour les dames began to appear with increasing regularity (Terrall 2000, 239-254; Sutton 1995; Pfieffer 1991). If Fontenelle had sketched the literary personification of the woman philosopher, it was the eighteenth century that fully brought her to life and encouraged male philosophers to imagine themselves in regular conversations with women about science. Just as Fontenelle had made his fictional conversations in science plausible by introducing key ingredients from his cultural milieu, his successors tailored their imaginary philosophers to fit the worlds they inhabited. And they did more than that. By returning frequently to the model invented by Fontenelle, they reaffirmed the plausibility of this scenario. Women could become philosophers in conversation with men. A bookish idea helped to solidify a social reality.

No admirer of Fontenelle believed this more fervently than the son of a Venetian merchant, Francesco Algarotti, who dedicated the first edition of his Newtonianism for Ladies (1737) to Fontenelle. Attracted to Newtonian natural philosophy as a young student in Bologna in the late 1720s, Algarotti saw the Cartesian world view collapse before his eyes in the face of more compelling English ideas. But he carried forward one important principle of Cartesian natural philosophy, namely, the idea that philosophy should be a pleasurable exercise of the mind in which women as well as men could understand and interpret nature (Harth 1992). Algarotti had good reason to believe this because of what he had observed in Italy, where learned women were increasingly celebrated for their engagement with modern philosophy and mathematics. No one more embodied this new vision of knowledge than the Bolognese physicist Laura Bassi. While the University of Bologna formally and publicly celebrated Bassi's mastery of traditional philosophy when they awarded her a degree and university professorship in 1732, it quickly became apparent that Bassi was attracted to more modern ideas and encouraged by a number of her male colleagues to pursue these interests (Findlen 1993; Berti Logan 1994; Ceranski 1996). Algarotti was well informed about these events because most of the key participants were friends from his student days in Bologna la dotta. He took a keen interest in the activities of Laura Bassi and wrote poems in honor of her degree (Cavazza 1990, 237-256). It was around this time that he began to think of rewriting Fontenelle.

Two years later in Rome, Algarotti drafted the first version of his dialogue on Newtonian optics. He subsequently completed it after traveling to France and England before returning to Italy. During his own version of a reverse Grand Tour to northern Europe, Algarotti discussed the contents of his Newtonianism with the likes of Voltaire, Émilie du Châtelet, and Lady Mary Wortley Montagu as well as with important mentors in Bologna such as Francesco Maria Zanotti, secretary to the 
Academy of the Institute of Sciences. He wrote his book in a fresh and lively Italian, peppered with English ideas and French phrases that outraged an older generation of readers. But Algarotti replied that he did this because he "wished to speak with the ladies of our century and not with the ladies of the fourteenth century" (Algarotti 1791-94, 10:197). ${ }^{2}$ It was a modern book for modern men and women.

Despite the controversy that Algarotti's work initially provoked in Italy, where it was placed on the Index of Prohibited Books almost immediately after its publication, though the Congregation of the Index ultimately accepted the corrections he made in his 1746 and 1750 editions, it remained an influential and popular work. Just as Newton supplanted Descartes, Algarotti soon rivaled Fontenelle as the popularizer of new ideas. ${ }^{3}$ Twenty years after the first edition of his Newtonianism appeared, Algarotti continued to think that most Italians wrote very little "for the instruction or pleasure of women" (Algarotti 1757, 1:393; Arato 1991, 41-80). He revised and refined his Newtonianism, more chastely titled Dialogue on Light, Colors, and Attraction as of 1750, for new generations of readers, making his work the most important popular account of modern natural philosophy in Italian in the eighteenth century and the most influential literary portrait of the natural philosopher after Fontenelle's Conversations.

Algarotti's Newtonianism told the tale of an aristocratic Italian woman who learned Newtonian optics from a philosopher during several days of conversation in her villa, set in the hills near Lake Garda (fig. 1). In many respects, he followed Fontenelle's model for conversation very closely, since his Marchesa became Newtonian after several days of conversation with her philosopher. Yet Algarotti took Fontenelle's idea at least one step further by referring to flesh-and-blood women philosophers who might serve as role models for his inquisitive Marchesa. The interaction between the fictional and real philosophers of his day made Algarotti's Newtonianism a more powerful text than Fontenelle's Conversations because he described a woman who was actually less learned than the most accomplished and celebrated women philosophers of the mid-eighteenth century.

Such women orbited in the vicinity of Algarotti's Newtonianism from its inception to the moment of its publication. Neither Laura Bassi nor Émilie du Châtelet, both well-known to Algarotti when he wrote his book and specifically mentioned by him, found much to praise in his account of a woman philosopher - in fact, Châtelet made a point of expressing her disappointment that Algarotti had attached her portrait to so frivolous a work (Ehrman 1986, 29-30). Milan, the city in which Algarotti printed his unauthorized 1737 edition without an ecclesiastic imprimatur when he could not

\footnotetext{
${ }^{2}$ For further discussion of the initial criticisms of Algarotti's book, see Zan 1981. The broader intellectual climate is discussed in Ferrone 1995.

${ }^{3}$ Of the eight known Italian translations of Fontenelle prior to the twentieth century, one is a manuscript in Bologna (Biblioteca Comunale dell'Archiginnasio, ms. 3768) dated 1730, prior to the publication of Algarotti's Newtonianism, while the other seven appeared subsequently in editions of his works published in Paris, 1748, Paris/Venice, 1749, Arezzo, 1751, Naples, 1765, Venice, 1785, Venice, 1797, and Naples, 1817. See Maugain 1923.
} 


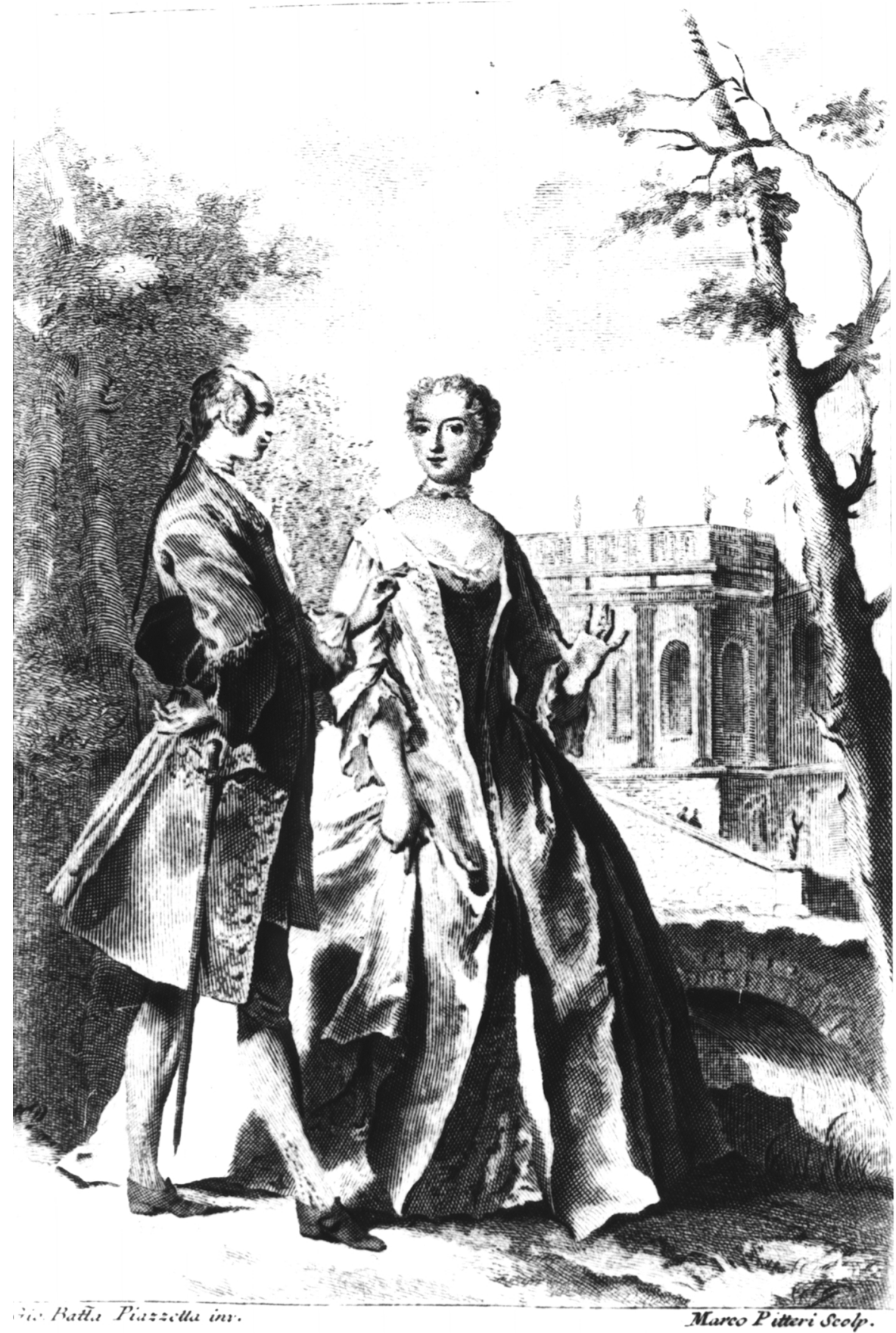

Fig. 1. Newtonianism for Ladies, 1737. Source: Francesco Algarotti, Neutonismo per le dame (Naples [Milan], 1737). Courtesy of the Biblioteca Comunale dell'Archiginnasio, Bologna. 
print it in Venice, boasted the presence of the learned Clelia del Grillo Borromeo, who had founded a scientific academy in the 1720s, and the talented Maria Gaetana Agnesi, who was then entertaining foreign visitors in her father's salon with her exposition of Newtonian natural philosophy. Naples, the city to which Algarotti falsely attributed the publication of his work, boasted a number of philosophical women, including the aristocratic Faustina Pignatelli whose knowledge of mathematics was widely admired throughout Italy (Findlen forthcoming; Findlen 1995; Mazzoti 2001). But they were not the audience he had in mind.

Just as Algarotti would later tell a friend that his dialogues were "not for scientific men," he also understood that he did not write for the women whom he admired. His book was for men and women who wanted to become scientific but did not have the skills or knowledge of a natural philosopher - a lay audience eager to participate in the pursuit of modern knowledge (Algarotti 1791-94, 9:355). ${ }^{4}$ The inclusion of a woman philosopher in the imaginary conversations about knowledge held near Lake Garda served a different function in the 1730s than it had in the 1680s because, if anything, it clarified the distance between the Marchesa and the most celebrated women natural philosophers of his day. There were actually two kinds of women natural philosophers in Algarotti's Newtonianism: the woman who already was fully scientific in her intellectual formation and the less educated woman on the verge of science, eager to become privy to nature's secrets. Both of them existed in relationship to the male philosopher, the former as a celebrated colleague in the Italian universities and academies, whose male members admitted a number of women into their ranks throughout the eighteenth century, and the latter as a potential pupil who might, with proper training, join the conversations that Algarotti could already have with Laura Bassi and her contemporaries. The gender of knowledge, in other words, had become more complicated since Fontenelle first penned his Conversations.

It is relatively easy to study the kind of person who became Laura Bassi, because we can document her progress from the year or so preceding her university degree until her death in 1778, based on forty-six years of teaching, experimenting, occasionally publishing, and corresponding with other natural philosophers throughout Europe. The same is also true of Châtelet who left behind a rich legacy of publications, including her French translation of Newton's Principia, and of Agnesi, whose contributions to Italian mathematics are well-documented. Understanding the place of the other kind of woman natural philosopher, a woman interested in scientific knowledge with very little access to formal institutions of research and learning, is much harder. One of the obvious reasons she is harder to find in reality than in fiction is because her interaction with scientific knowledge was much more ephemeral, a more fleeting encounter with the world of ideas that produced few

\footnotetext{
${ }^{4}$ Algarotti specifically uses the term uomini scienziati rather than "philosophers" in this discussion.
} 
tangible products. In the end, however much she wanted to become a scientist, she rarely succeeded. ${ }^{5}$

It is possible to construct a different scenario, however. Let us imagine some of the readers of Fontenelle and Algarotti - not the well-informed male readers who saw no profit in such books or the learned female readers who considered themselves rendered ridiculous in print, but those men and women who knew little of science but wanted to know more. The provincial towns of eighteenth-century Europe were populated with this kind of savant. They consumed works such as the abbé Noel de la Pluche's immensely popular Spectacle of Nature, another example of a work that introduced its readers to natural history through scientific dialogues that prominently included women (Pluche 1741-82; Roche 1978). There is every reason to believe that they would have read Fontenelle and Algarotti in a different way than a reader informed in the latest developments in natural philosophy. Such readers, I am suggesting, found popular works of science informative and engaging, and were more predisposed to take literally the suggestion that the fictional characterizations of male and female philosophers might be the starting point for cultivating a more scientific character. Such scholars were, in large part, provincial observers of events that occurred in more cosmopolitan settings, people who read about Laura Bassi, for instance, but never actually met her. For this audience, the realities of women natural philosophers and their fictional representations all merged into a world of news conveyed by letters, journals, and books that recorded the events of the day. It is relatively easy to understand how and why someone became a scientist in a major intellectual center, rich with institutions, opportunities, and intellectual models to emulate. But it is much more revealing to see how this sort of aspiration was nurtured in a small town, far removed from any university or major scientific academy, where intellectual resources were indeed scarce. In such settings, who was to say if Fontenelle's and Algarotti's fantasies of science might not come to life?

\section{In Search of Science}

Lake Garda, the fictional setting for Algarotti's Newtonianism for Ladies, did indeed have its natural philosophers, or at least those who aspired to science. In his dialogue, Algarotti poetically recalled the "verdant hills of Salò ... and the lake dotted with shimmering images of boats and little islands." He took his Marchesa and her philosopher on a boating excursion on the lake so that they might see how "in the moonlight, the waters of the lake seem to tremble" (Algarotti [1969] 1977, 9, 97).

\footnotetext{
${ }^{5}$ Readers should be aware that the term "scientist" is largely a nineteenth-century word that replaced terms such as "natural philosopher" that preceded it. For the sake of emphasis in this article, however, I am occasionally using the modern term in juxtaposition to this earlier vocabulary to highlight the distinction between someone whose mastery of natural knowledge led them to teach, experiment, and publish on scientific matters, and the idea of philosophizing about nature that was a much more open-ended and inclusive activity, especially in the eighteenth century.
} 
The landscape he evoked is still there to be seen. The small city of Salò, located on the shores of Lake Garda in proximity to the prosperous industrial city of Brescia in the Venetian Republic, was a town of pale yellow and green aristocratic palaces, pleasure boats, and leisure. One of the favored sites of the Venetian villeggiatura, the summer retreat from the city famously satirized by Carlo Goldoni, it was sufficiently removed from the intellectual centers of Bologna, Padua, Milan, Rome, and Naples, where debates about natural philosophy flourished, to seem a provincial backwater. Yet science was very much on the minds of the Salodian elite in the middle of the eighteenth century. Discussions of the mechanisms of the senses, the nature of light, the circulation of the blood, and the flux and reflux of the sea animated the meetings of their local academies. ${ }^{6}$ Their passion for science reflected the general fascination with such subjects at the time. But it also seems to have been a product of reading Algarotti's book, which had suggested to them, of all readers, the possibilities of forming a scientific culture in a small Venetian town.

Algarotti had used the beauty of Lake Garda to good effect in describing a leisured environment in which scientific conversations among men and women could flourish. At least one woman in the city of Salò thought carefully about the possibilities that he - and more generally her world - suggested. In 1764, she finally acted on what she had read, giving the Salodian and Brescian elite something to talk about. That year, in a small academy whose meeting rooms overlooked the shores of Lake Garda, the Brescian poet Diamante Medaglia Faini (1724-1770) declared to her fellow members of the Accademia degli Unanimi that she would give up poetry in order to become a mathematician.

Medaglia Faini did this, appropriately enough, with a poem - the last of more than one hundred poems she is known to have written and published. In a remarkably personal and eloquent expression of her frustrations with the intellectual conventions of her day, she rendered into poetry a brief history of a stifled life of the mind, constrained by the social expectations of women in her society. In her final poem, she spoke of the utter uselessness of her poetry and her pleasure at turning her thoughts to geometry and astronomy:

I who until now for so many requests have composed

sonnets, stanzas, and madrigals

for physicians, brides, and lawyers,

and for those who take the veil and sacred robe;

No longer want to rack my brains

without profit and waste time on such things

rather I wish to move

to the highest sign that awakens my desire.

\footnotetext{
${ }^{6}$ Biblioteca dell'Ateneo, Salò, ms. 101 (c. 23), n. 4 (Registri de' Ragionamenti recitati nell'Accademia detta de' Discordi di Salò, ed ora de' Pescatori Benacensi). See the entries for 7 May 1761, 11 March 1762, 18 April 1763, and 5 May 1763. See also Bustico 1913.
} 
Far from Apollo in Euclidean papers

I now sweat and also am pleased to spy upon

what Jove, Saturn and Mars do above.

Whoever therefore takes pleasure in poetic collections

(thankfully the vast heavens distribute them to many)

do not dare whatsoever to disturb my peace!

(Medaglia Faini 1774, 163)

Four years after her death, the engravings that accompanied a 1774 posthumous edition of Medaglia Faini's writings allegorized her transformation from a poet into a mathematician (fig. 2). But they did not tell the story in quite the same way. Instead the engraver Saverio della Rosa depicted Faini as ascending to Parnassus accompanied by a poetic muse, her feet resting on an open book and her head about to be crowned with a wreath of laurels. The laurels were the traditional poet's crown but they were also, by the eighteenth century, an important symbol of the woman natural philosopher, since Laura Bassi was depicted on numerous occasions after her degree as wearing a silver crown of laurels and was ultimately buried with it in 1778 (Findlen 1993). The words beneath Medaglia Faini's portrait underscored her ability to combine the virtues of art and science: "Faini is worthy of a chorus represented by a trio with the voice of the Muses, the eyes of the Graces, and the mind of Minerva" (fig. 3). The male scholars most admiring of Medaglia Faini's accomplishments, in other words, saw her pursuit of natural philosophy as the pinnacle of her accomplishments rather than a negation of all that had preceded it. She was a poetic Venus who had become Minerva.

Exactly when Medaglia Faini conceived the idea of becoming a mathematician is unclear. She certainly did not find it in the pages of Fontenelle or especially Algarotti, neither of whom encouraged their women readers to understand the mathematics of Cartesian and Newtonian philosophy. Her models for this kind of natural philosophy were surely living rather than fictional, though she conceived of her own transformation in highly literary terms. Her surviving correspondence indicates that she had begun to pursue this line of inquiry at least several years before she publicly announced her conversion to mathematics. Responding to a colleague who had sent her four sonnets in May 1758, Medaglia Faini wrote, "I am sorry that I don't presently have anything to exchange in response to your kind act, because everything that I usually dedicated in the past to the Muses is now consecrated to philosophical studies" (Medaglia Faini 1774, 225). At some point in her early thirties she began to envision herself as a natural philosopher. In her mind, this meant a cessation of poetic activities, something most of her male colleagues would not have understood since they found science and poetry to be compatible pursuits.

The timing of Medaglia Faini's decision coincided with the flourishing of natural philosophy in mid-eighteenth century Italy. The 1750s may well have been the high point for women's participation in natural philosophy. In that decade, no less than three women - Bassi, Agnesi, and the anatomist Anna Morandi Manzolini - held 


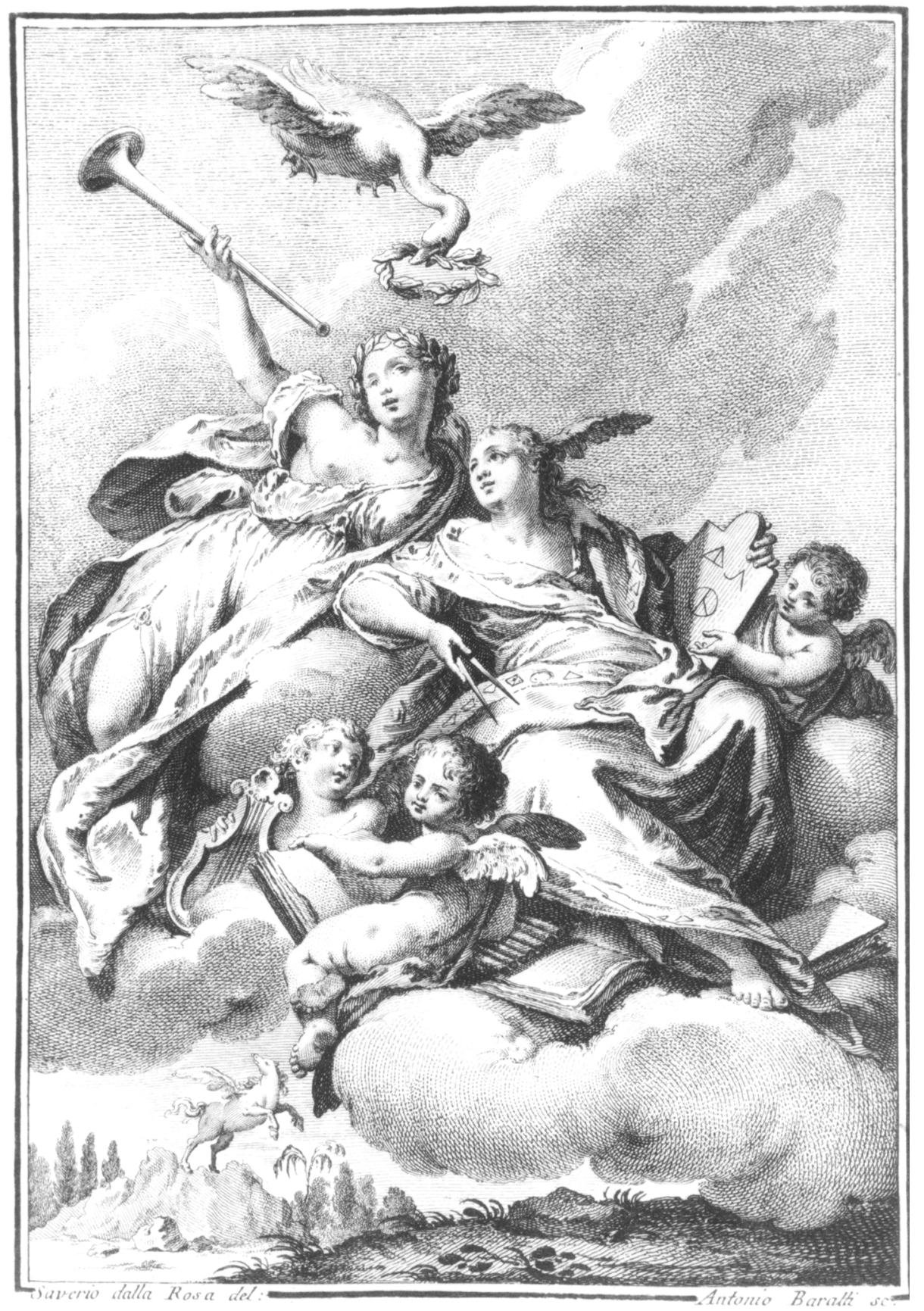

Fig. 2. The transformation of Diamante Medaglia Faini from poet to mathematician. Source: Diamante Medaglia Faini, Versi e prose di Diamante Medaglia Faini, edited by Giuseppe Pontara (Salò, 1774). Courtesy of the Biblioteca dell'Accademia dei Concordi, Rovigo. 


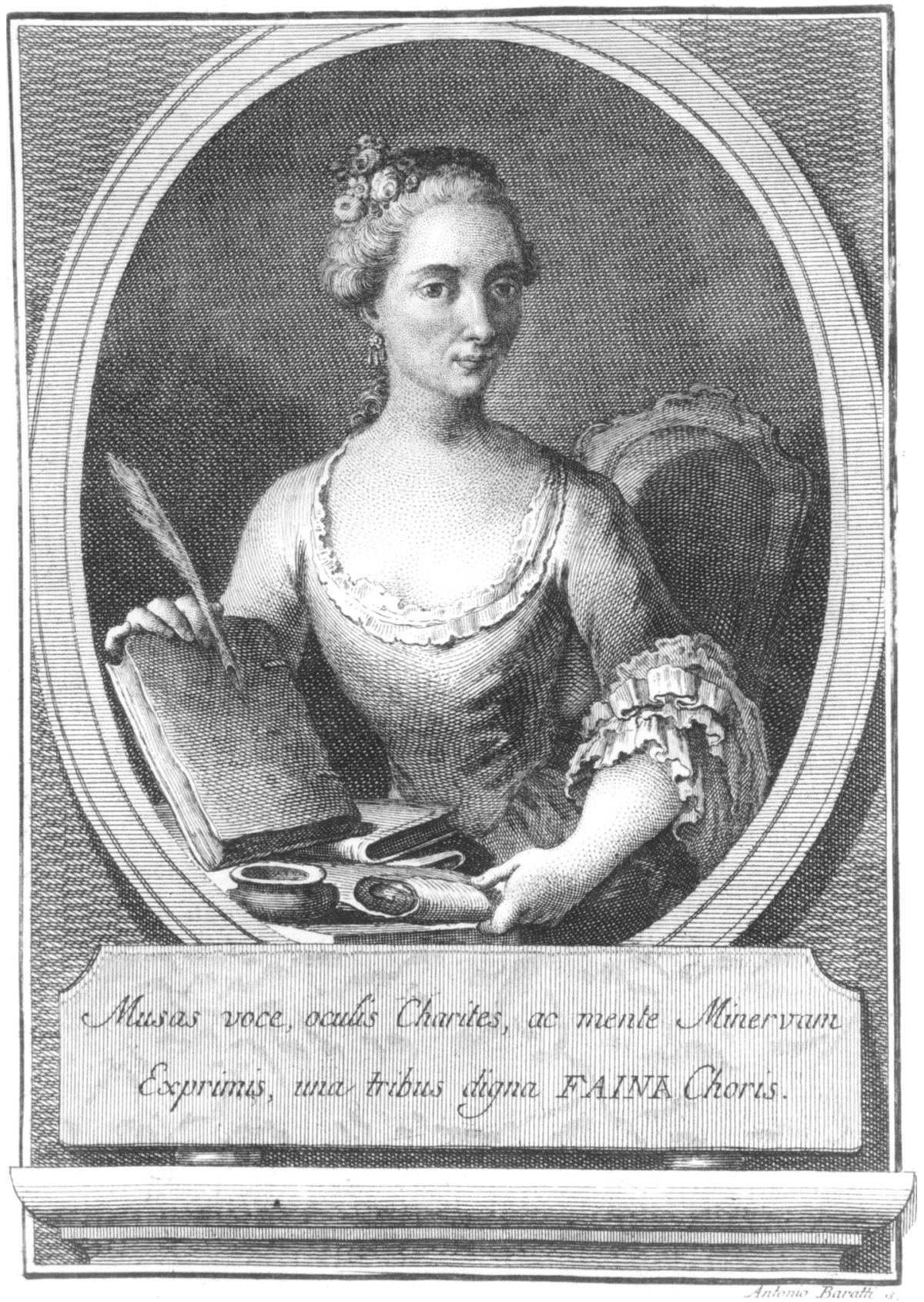

Fig. 3. "Faini is worthy of a chorus represented by a trio with the voice of the Muses, the eyes of the Graces, and the mind of Minerva." Source: Diamante Medaglia Faini, Versi e prose di Diamante Medaglia Faini, edited by Giuseppe Pontara (Salò, 1774). Courtesy of the Biblioteca dell'Accademia dei Concordi, Rovigo. 
professorships at the University of Bologna, and several more had been admitted to the Academy of the Institute of Sciences. ${ }^{7}$ Châtelet's translation of Newton's Principia, completed in 1749, would not appear in print until 1759, but Agnesi's Analytic Institutions for the Use of Italian Youth (1748) offered strong evidence of women's ability to pursue the most difficult and abstruse aspects of analytic geometry and calculus. And the stories of women graduates continued to circulate. In 1751, Bologna had conferred a degree upon its second woman graduate, Cristina Roccati, considered by many contemporaries to be another Laura Bassi (Findlen 1999; Soppelsa and Viani 1999). Roccati lived in the same region of Italy as Medaglia Faini, since her town of Rovigo was also part of the Venetian Republic, near enough to Salò for them to correspond and have some common acquaintances. In April 1763, Medaglia Faini wrote to a friend who was visiting Rovigo and had sent her greetings to Roccati, who by then was professor of physics at the Accademia dei Concordi: "Please thank her most warmly in my name and remind her again how much I am a devoted admirer of her valor" (Medaglia Faini 1774, 183). Roccati, in other words, was the very model of a mathematical woman that Medaglia Faini hoped to emulate and most likely the direct source of her inspiration to become a mathematician.

As part of her growing interest in natural philosophy, Medaglia Faini composed an oration on women's education which she gave before the Accademia degli Unanimi on 5 May 1763, the day that she was elected head of the academy. ${ }^{8}$ During the preceding month, when she sent her greetings to the physicist Roccati, she was hard at work on composing this treatise; in August, she sent a copy to the historian Lucio Doglioni, who eventually gave it to Giuseppe Pontara to include in the 1774 collection of her work (Medaglia Faini 1774, 184-185). ${ }^{9}$ Her oration addressed both the historical and contemporary problems of women's education. Invoking the conclusion of a famous debate held at the Accademia de' Ricovrati in Padua in 1723 on the question, "Should women be admitted to the study of the sciences and the noble arts," Medaglia Faini examined the appropriateness of different kinds of knowledge for women in her own day. But she did not simply argue that women of high social standing had the capacity to be learned, as the Paduan academicians had concluded forty years earlier, the year before her birth. In the spirit of mid-eighteenth century educational reformers, Medaglia Faini emphasized the utility of women's

\footnotetext{
${ }^{7}$ While Agnesi never accepted the professorship in mathematics she was offered in 1750 , the university records continued to list her as one of their professors for decades and she was often publicly described as a Bologna professor, despite the fact that everyone knew she had never left Milan.

${ }^{8}$ Biblioteca dell'Ateneo, Salò, ms. 101 (c. 23), n. 4 (Registri). The entry for 5 May 1763 reads: "Lesse una dotta dissertazione la Sig.a Diamante Medaglia Faini degli studi delle donne dimostrando che si conviene anche a loro attendere agli studi ed diquali." The Accademia degli Unanimi had existed erratically since 1564 and underwent a revival in 1733. In 1761, a split between the members produced a new academy, the Accademia de' Discordi, which included the presence of women. One year later, they renamed themselves the Accademia dei Pescatori Benacensi and, by 1763, had rejoined the Unanimi (see Pasero 1969, 1: 45, 69-73; and Bustico, 1913, 132-138).

${ }^{9}$ The only detailed modern study of this treatise appears in Messbarger (2002). A translation of this treatise will appear in Messbarger and Findlen (forthcoming).
} 
learning. "For it is certain," she argued, "that the female sex should not take up all disciplines without distinction, abandoning itself to its own caprice. Rather women should study those which, by their nature, can bring some utility and greater benefit" (Medaglia Faini 1774, 168). Making women philosophers was a social imperative rather than simply an act of personal fulfillment. For this reason, Medaglia Faini spoke of women in the plural, in contrast to her contemporaries who delighted in celebrating singular female prodigies of intellect.

Medaglia Faini's goal, as she wrote on several different occasions, was to elevate mathematics as a foundation for all knowledge and to universalize it as a kind of knowledge that men and women enjoyed equally. While she also urged her listeners to encourage women to study philosophy and experimental physics, she made it clear that she considered geometry to be the analytic foundation of all modern sciences, the epistemic origins of knowledge. "By your marked silence, I know that you are in full agreement and hold what I say to be true," she declared to her fellow academicians:

So without further delay, I repeat: If women lend their labor to mathematics, to mathematics, they will no longer see themselves fall into crass paralogisms, or other errors that at times even learned men who are not mathematicians make.

Medaglia Faini contrasted the universal value of mathematics to the less essential nature of poetry, citing Giulio Cesare Becelli who had argued that "poetry was the less necessary discipline." She criticized women for wasting their minds on frivolous poetry that was pleasing to hear but devoid of any lasting value. "I hope I do not err in asserting frankly that performing poetry in this fashion is the surest way to condemn oneself" (Medaglia Faini 1774, 176, 171; Becelli 1738). She reserved her praise only for philosophical poets who used their talents at verse to express profound truths. Philosophy disciplined the mind and, as a good post-Cartesian, she believed that mathematical philosophy accomplished this task better than any other kind of logic.

The debate about the relative merits of poetry and science was very old, but it took on new life in a world in which Algarotti's Newtonianism opened with a discussion of Alexander Pope's poems. Medaglia Faini participated in a wider debate about the uses of poetry in her society that increasingly questioned its function in relation to new kinds of knowledge. The famous Parma lyric poet Carlo Innocenzo Frugoni, advising a young male colleague in 1767 on the best way to make one's reputation in the republic of letters, wrote that poetry was no longer as fashionable as it had once been in his youth:

To gain a name for yourself, you must do metaphysics and mathematics; poetry is nothing more than pleasing prattle. The republic [of letters] gains no benefit from it, 
indeed we should exile it as a seductress or harmful woman who lures away minds from better studies. ${ }^{10}$

Frugoni's metaphor of poetry as a seductive woman had a special resonance with the circumstances of Medaglia Faini's complaint since the majority of learned women in Italy were celebrated for their poetry. Many writers argued that poetry was the learned woman's special calling because it was in her nature to be poetic (Graziosi 1992; Anon., 1789, 219-220). If Frugoni ironically described poetry as "the most useless thing in the world," responding to arguments in favor of intellectual utilitarianism, we can only imagine how Medaglia Faini must have felt about the idea that the object of her initial fame was increasingly a trivial pursuit.

In 1763, the year in which Medaglia Faini began to criticize poetry publicly, she was thirty-nine years old and well known throughout the Veneto as one of the most prolific female poets of her generation. The daughter of the Brescian physician Antonio Medaglia and Annuziata Gnecchi di Casto, she had been educated by her great-uncle. "She embraced ardently all the books that fate placed in her hands," wrote the local historian Antonio Brognoli in 1785, "but took particular delight in the harmonic sound of the verses of the Italian poets" (Brognoli 1785, 259). By the late 1730 s and early 1740s, she was known locally as a great admirer and imitator of Cinquecento poetry, and became a figure of some note in the salons and academies around Brescia. Invitations to publish her poems followed. Medaglia Faini evidently enjoyed her celebrity, later writing one poem about her heady Olympian ascent:

Desirous of eternal fame, my foot turned to ascend the sacred mountain of Parnassus in order to decorate the still grassy knoll on which Apollo gathers with his dearest companions.

Yet as Faini also observed, such moments were bittersweet. Such an ascent was inevitably accompanied by the dangers that accompanied one's entrance into a more public arena of knowledge. "I fell, and no one . . helped me or thought me in great peril," she reflected bitterly. Addressing this reflection to a young male poet, she observed: "This will not happen to you" (ibid., 262).

At various moments in her life, Medaglia Faini was forced to reexamine her intellectual ambitions. In 1748, twenty-four-year-old Diamante Medaglia married the physician Pietro Faini, and moved to Salò. There is some indication that her father had encouraged her to marry because he was afraid his daughter had fallen in love with learning. Contemporary biographers also noted that her father-in-law was unhappy with her public displays of knowledge. Friends feared that she would give up poetry because of her marriage, to which Medaglia Faini replied: "Do not fear or

${ }^{10}$ Getty Center, Los Angeles, Lettere di italiani eruditi, vol. 226, n. 17 (Abbot Carlo Innocenzo Frugoni to L. A. Loschi, Parma, 7 April 1767). Frugoni was seventy-four when he wrote this letter so he certainly represented a different generation. 
suspect that I could abandon the muses" (ibid., 264-265; Pontara 1774, xiv). ${ }^{11}$ In light of her subsequent decision to pursue mathematics, such a statement has a delightful irony about it. But it also reveals Medaglia Faini's strong sense of conviction about the worthiness of her scholarly pursuits. At least through the 1740s, she saw poetry as intellectually fulfilling.

What happened to change her mind? By the late 1750s, Faini had tired of the ceremonial world of poetry, which demanded a great deal of her time, writing poems for weddings, investitures, the entrance of the Venetian doge, and other social functions, and publishing them in a succession of volumes that contemporaries described as the "whip, misfortune, cancer, and plague of poets" (Brognoli 1785, 266). Her high level of visibility led to her admission to several academies, including the Agiati of Rovereto in 1751, the Orditi of Padua, and the leading literary academy of the day, Arcadia, in 1757 (ibid., 271; Bustico 1929; Ebranati 1989, 95-97). Despite these external signs of success, I am tempted to think that they only exacerbated her frustration. To be recognized for something that one does not really value is hardly a success. Dispirited, Faini characterized her later poems as "better than terrible." 12 We might describe them instead as a marvelous social critique of the place of culture in her society. Take, for instance, a poem she wrote shortly before her final rebellion against poetry:

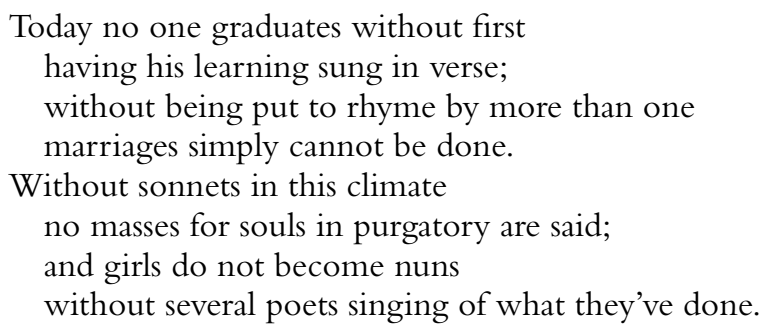

It was also in this poem that she expressed the feeling that "Apollo is now adverse to me in every way" (Medaglia Faini 1774, 163; Brognoli 1785, 268-269).

As a poet disillusioned with her first calling and in search of something more fulfilling, Faini had ample opportunity to reflect on the other forms that learning might take. Algarotti's Newtonianism provided an excellent guide, though it was hardly the sole source of her inspiration. New editions of this controversial work appeared in $1746,1750,1752,1757$, and $1764 .{ }^{13}$ Algarotti himself returned to the Veneto from his travels in the early 1750 s, so it is not unlikely that the two may have met or had mutual friends. The reappearance of Algarotti's book provoked further criticisms and

\footnotetext{
${ }^{11}$ See also Biblioteca Civica Queriniana, Brescia, ms. K.IV.49, pp. 50-51, 63 (Jacopo Guzzaga, Memorie di letterati bresciani. n. 2bis. Vita di Diamante Medaglia Faini).

${ }^{12}$ Biblioteca dell'Ateneo, Salò, Ms. 133 (C.55), fasc. A [letter to Doglioni?, n.d.]

${ }^{13}$ For a complete publication history of Algarotti's Newtonianismo, see Arato 1991, 135-155.
} 
new imitations, engendering a public debate in print about the desirability of modern philosophizing. Abbot Giovanni de Cataneo's Philosophizing for Beauties (1753), for example, offered a scathing critique of the kind of education that Algarotti proposed. Imagining the library of a woman philosopher in the Veneto, de Cataneo described a table strewn with "the Plurality of Worlds, Fontenelle, Newtonianism for Ladies, and other works of the same taste." He systematically attacked the impiety of the Cartesian, Lockeian, and Newtonian worldview that such works represented, and derided those who believed that mathematics could be a universal language for knowledge. "You will quickly discover what trickery this is," he wrote. "Few men have the talent and ability to mathematicize and, at best, two women in the world" (Cataneo 1753, 9, 20). ${ }^{14}$

Medaglia Faini obviously did not agree with this assessment, either of mathematics or of women's ability to master this discipline. Instead, she sided with Enea Gaetano Melani, whose Book for Women (1757) appeared in Venice in the years in which she began to consider the absence of mathematics and philosophy in women's education. In his ambitious program of learning, which included the creation of an entire library written solely for women readers on every subject that he deemed appropriate to their education, Melani argued that philosophy was absolutely fundamental to women's education because it taught virtue and discipline and instilled them with a critical capacity for self-knowledge. Medaglia Faini echoed his arguments when she wrote that "the great advantages that can be gained from philosophy lead me to exhort young women not to neglect to apply themselves wholly to such an important science, of which they are capable" (Medaglia Faini 1774, 172; Melani 1757, esp. pp. 1-37).

While such treatises inspired the content of Medaglia Faini's Oration, it was Algarotti's fictional account of how a Salodian noblewoman became Newtonian that provided the template for key aspects of her intellectual transformation. Algarotti implicitly suggested that discussions of science could emanate from poetry, when he opened Newtonianism for Ladies with an account of Alexander Pope's poems on Newton, as a prelude to explaining the Opticks. At times, Algarotti's Marchesa might literally have provided the words that shaped Medaglia Faini's decision. In the second day of the dialogue, in response to a bumbling Arcadian poet, signor Simplicio, who kept interrupting the Marchesa's conversation with the philosopher to talk about things other than Newton, she tartly declared, "I would like now to cease being poetic" (Algarotti [1969] 1977, 49). Nowhere did Medaglia Faini cite Algarotti in her oration or in her poems about the demise of her poetic career. Yet it seems clear that she had read his book and absorbed his image of the woman philosopher as an expoet, though she evidently diverged from Algarotti in her conception of the kind of philosophy appropriate for women.

\footnotetext{
${ }^{14}$ In all likelihood, the two women de Cataneo had in mind were Bassi and Agnesi.
} 
There was some truth to this image beyond Algarotti's words. Most women philosophers in the eighteenth century were often renowned for their poetry and quite ambivalent about it. Bassi, for instance, complained publicly about being forced to write poetry in the years following her degree and professorship, when she felt that her talents lay elsewhere. In February 1737, she wrote to the Bolognese poet Giampietro Zanotti that she had "no desire to compose poetry ever again" (Melli 1960, 82). Roccati also expressed ambivalence about her reputation and obligations as a poet. As a university student in Bologna in 1750, she told her patrons that she was too busy with her studies to continue to invent poems for them. ${ }^{15}$ Medaglia Faini admired Roccati greatly and closely identified with her, as a woman of the same generation who also lived in a small Venetian town. Both of them contributed to published collections of poetry so they belonged to a Venetian republic of women that included philosophers as well as poets. We do not know exactly what Medaglia Faini had heard about Bassi but news of her degree and professorship had made it all the way to Salò, including notices of poems written in her honor. ${ }^{16}$ Thus, when Medaglia Faini praised philosophy, experimental physics, and mathematics in her 1763 oration, and encouraged women to give up poetry for these more useful subjects, she invited them to imitate the actions of the leading women philosophers in Italy. If her conception of a woman philosophizing began with Algarotti's playful sketch of a poetic woman on the verge of science, it ultimately moved well beyond it, since Medaglia Faini took seriously the idea that women could understand even the most difficult aspects of natural philosophy.

Medaglia Faini's own intellectual reinvention represented an attempt to enact personally what she proposed generally. In his Book of Women, Melani had encouraged women to become learned enough so that they might educate other women. "One good male teacher can instruct a few women who will then become teachers of many, many other women" (Melani 1757, 137-139). Science for the many rather than science for the few. Algarotti died in Pisa in May 1764, the year Medaglia Faini seems to have written her last poem, having never intended his book to educate more than a few noblewomen because he was writing as much for the delight of his male readers as for a female audience. That year his Caritea was published in Livorno. It began with a conversation between a Venetian noblewoman and Algarotti. She had read the latest version of his Newtonianism and now wanted to discuss natural philosophy with him (Algarotti 1791-94, 2:347-365). In the hands of certain readers, Algarotti's model of the aristocratic woman philosopher became a starting point for a world of educated scientific women, to such a degree that Algarotti himself was compelled to imagine what the women who read his earlier work might be inspired to discuss because of their encounter with his dialogues.

\footnotetext{
${ }^{15}$ Biblioteca dell'Accademia dei Concordi, Rovigo, Silv. 195, no. 32 (Roccati to Silvestri, February 1751).

${ }^{16}$ Biblioteca dell'Ateneo, Salò, ms. 165 (D. 11). This volume contains a copy of a letter from Giampietro Zanotti to his sister Anna, then living in Castelfranco (Bologna, 1 October 1732). It is a fine example of how important news traveled through copies of letters as well as printed journals and reports from travelers.
} 
It is hard to think of the timing of Medaglia Faini's decision as coincidental. Algarotti was not her sole source of inspiration, but one of several factors that helped to crystallize her vision of a world in which women regularly participated in science. She wanted perhaps to become the next Laura Bassi, or at the very least a colleague of her fellow Venetian Roccati who was valiantly trying to educate one small Venetian town in the mysteries of mathematical and experimental physics. Out of the fictional Salò of science, a woman mathematician had emerged.

\section{Fontenelle in Salò, Or Mathematics in the Villa}

In order to pursue mathematics, Medaglia Faini needed a tutor. This brings me to the second part of my story, for we cannot understand the context of her decision without exploring the attitudes of the men with whom she interacted. One of the striking features of Fontenelle's and Algarotti's dialogues was the absence of the husband in the aristocratic home, who seems to have vacated the villa in order to let his wife enjoy her solitary conversations with a male tutor. Faini's husband Pietro did the same. In 1764, she left their home for three months to live in the villa of Count Giambattista Suardi (1711-67) and his wife Cecilia Curvi so that she could study mathematics. Suardi placed his intellectual resources at her disposal during an intense three-year relationship in the final years of both of their lives, since he was dead by 1767 and she by 1770 . Knowing something of his life and work allows us to understand more fully the cultural context in which both of them conceived of their relationship, since he was certainly the philosopher to her Marchesa.

Count Suardi - the man whom Faini called "a most loving patron, indeed a second father" - understood well what it meant to have a frustrated intellectual life (Medaglia Faini 1774, 195). Educated by the fine cadre of Brescian mathematicians who taught in the local seminaries and Jesuit colleges of the region, Suardi developed an early passion for mathematics and poetry. His father did not share these interests and sent him to the University of Padua to study law. Having spent the better part of four years sneaking into the mathematics and experimental physics courses of such luminaries as the famed Paduan professor Giovanni Poleni, Suardi made a sorry excuse for a lawyer upon his graduation in 1735. He returned to Brescia with the degree in hand and did his best to avoid having any career. Fortunately a sickly constitution provided a perfect excuse to remain in the library rather than enter the courtroom. By the late 1740s, Suardi ran an informal scientific academy from his house. He seems to have figured out, in the manner of his hero Descartes, that the best way to become a natural philosopher was to remain utterly at leisure.

In the early 1750 s a series of fortunate coincidences launched Suardi's public career as a mathematician. Years after he had begun a study of mathematical instruments, which included a description of his own invention, the "geometric pen," Suardi finally brought this work to a conclusion, publishing his New Instruments for the Description of Diverse Ancient and Modern Curves (1752). The possession of a 
publication, describing ten instruments that he had invented to draw many of the mathematical figures whose study analytic geometry and calculus encouraged, now offered Suardi an opportunity to build a reputation. He sent his book to famous mathematicians and learned academies, and was rewarded in 1753 with membership in the Agiati of Rovereto (which had admitted Faini in 1751) and in the Academy of the Institute of Sciences of Bologna, Italy's equivalent of the Royal Society of London and Paris Academy of Sciences. He wrote to one friend in Bologna of his pride in becoming "a member of such a distinguished Academy," professing surprise that they had admitted him on such slight accomplishments. "In any case, I'm an Academician, and, once others know this, they will consider me to be much more than I am." ${ }^{17}$ As if to punctuate his belated intellectual success, Suardi's unsympathetic father died in December 1754, leaving him free to pursue mathematics full-time. ${ }^{18}$ By 1764 , he had completed his Mathematical Treatises, which now proudly bore his academic affiliations as well as his place of birth (Suardi 1764).

Suardi did what any man in his position and with his passions would have done: he immediately packed his bags and toured the great scientific cities of Italy, returning to Padua to converse with his aging physics professor and traveling to Bologna and Milan to meet other mathematicians, visit observatories, and generally feel more connected to the broader intellectual world he aspired to enter. Like many other scholars of his generation, he probably encountered some of the famous women philosophers in these cities. Knowing his character, it is quite likely that he went out of his way to meet these prodigies of nature and intellect - and we should keep in mind that he was an exact contemporary of Laura Bassi, having been a student at Padua in the year she received her degree. Suardi returned home to Brescia late in 1756, now an academician in contact with the wider world of learning.

Suardi had several aspirations for his late-blooming career as a mathematician. He hoped to publish vernacular mathematics textbooks that would advertise his inventions and impart knowledge of analytic geometry, and, to a lesser degree, differential and integral calculus to a broader readership. In this he succeeded, joining a handful of scholars such as the celebrated Milanese mathematician Maria Gaetana Agnesi, whose Analytical Institutions had been the first Italian mathematics textbook to cover the entire range of developments from Cartesian geometry to Leibnizian and Newtonian calculus (Findlen 1995; Mazzoti 2001). He also wished to be recognized as an inventor of ingenious instruments that transcended the divide between theory and practice. Finally, and most interestingly for the story of his relationship with Medaglia Faini, he wanted desperately to become a mathematics tutor to a female prodigy.

\footnotetext{
${ }^{17}$ Biblioteca Comunale, Forlì, Autografi Piancastelli (Giovanni Battista Suardi) (Suardi to Petronio Mateucci, Brescia, 10 November 1762).

${ }^{18}$ The biographical details of Suardi's life can be found in Brognoli 1785, 147-169; and Biblioteca Civica Queriniana, Brescia, Ms. K. V. 49 (Guzzaga, Memorie, n. 4. Vita del Conte Giambattista Soardi Bresciano).
} 
Medaglia Faini of course was a little mature to merit the label "prodigy" when she commenced study with Suardi at the age of forty-one (and he at fifty-three). But she had been a literary prodigy in her youth so tinges of the glory remained. She enthusiastically submitted herself to his lessons in Euclid's Elements during the period in which Suardi was preparing his Mathematical Treatises. Writing to her friend Lucio Doglioni in July 1765, Medaglia Faini described her happy time at Suardi's villa and hoped that a recent illness would not detain her long from her studies. "If it pleases God to restore me to health, I will continue always the career I have taken up, delighting myself greatly with this subject," she declared (Medagli Faini 1774, 189). In appreciation for Suardi's tutelage, she translated into Italian a Latin poem Suardi had written to his wife. Interestingly enough, while Suardi described his own activities in 1764 as those of "a dilettante who occupies himself [with mathematics] for pleasure and not for duty," Medaglia Faini envisioned her own intellectual transformation as a second career (Suardi 1764, 1).

The story of Medaglia Faini's life as a mathematician stops here, making it a very brief career indeed, if we would even call it that since she does not seem to have progressed beyond Euclid with her tutor. After 1765, her frequent illnesses and bouts with depression kept her at home with her husband in their villa, forcing her to correspond at a distance with Suardi. In March 1767 Suardi died, leaving her bereft of a tutor. While numerous poems survive in her hand, we have not one scrap of her mathematical labors. Faini continued to see herself as a spokesperson for mathematics until the end of her life, and encouraged others in their pursuit of this science (Medaglia Faini 1774, 220). But we know very little about what it meant for her to realize her scientific aspirations.

This leaves us, instead, with her tutor Suardi's ambitions, which were more clearly delineated in his publications. We know a great deal about what he hoped to do, were he ever fortunate enough to acquire a talented female pupil. Suardi had many models upon which to draw. He was an enormous fan of the work of Agnesi whose own tutor, Ramiro Rampinelli, also came from Brescia. Rampinelli was surely Suardi's most immediate role model because he, too, had had a difficult entry into his chosen vocation, which his family had not supported (Torriceni 1760; Succi 1992). Suardi memorialized this earlier relationship between a female mathematician and her male tutor by having one of his inventions, the geometric pen, draw a mathematical form strongly associated with Agnesi and often erroneously presented as her discovery - a cycloid still informally known due to a rather Freudian mistranslation of the Italian term versiera as "the witch of Agnesi" (fig. 4). Suardi demonstrated his ignorance - or deliberate omission - of the preceding century's work in geometry when he presented it as "not having been known before by others" (Suardi 1752, 5; Agnesi 1748; Truesdall 1992). Tracing and retracing this curve, Suardi imagined himself in actual physical contact with the mind and perhaps the body of a learned woman. His pen made mathematics a sensory pleasure for all to pursue regardless of their ability to plot the parabolic path a particular curve might take. 


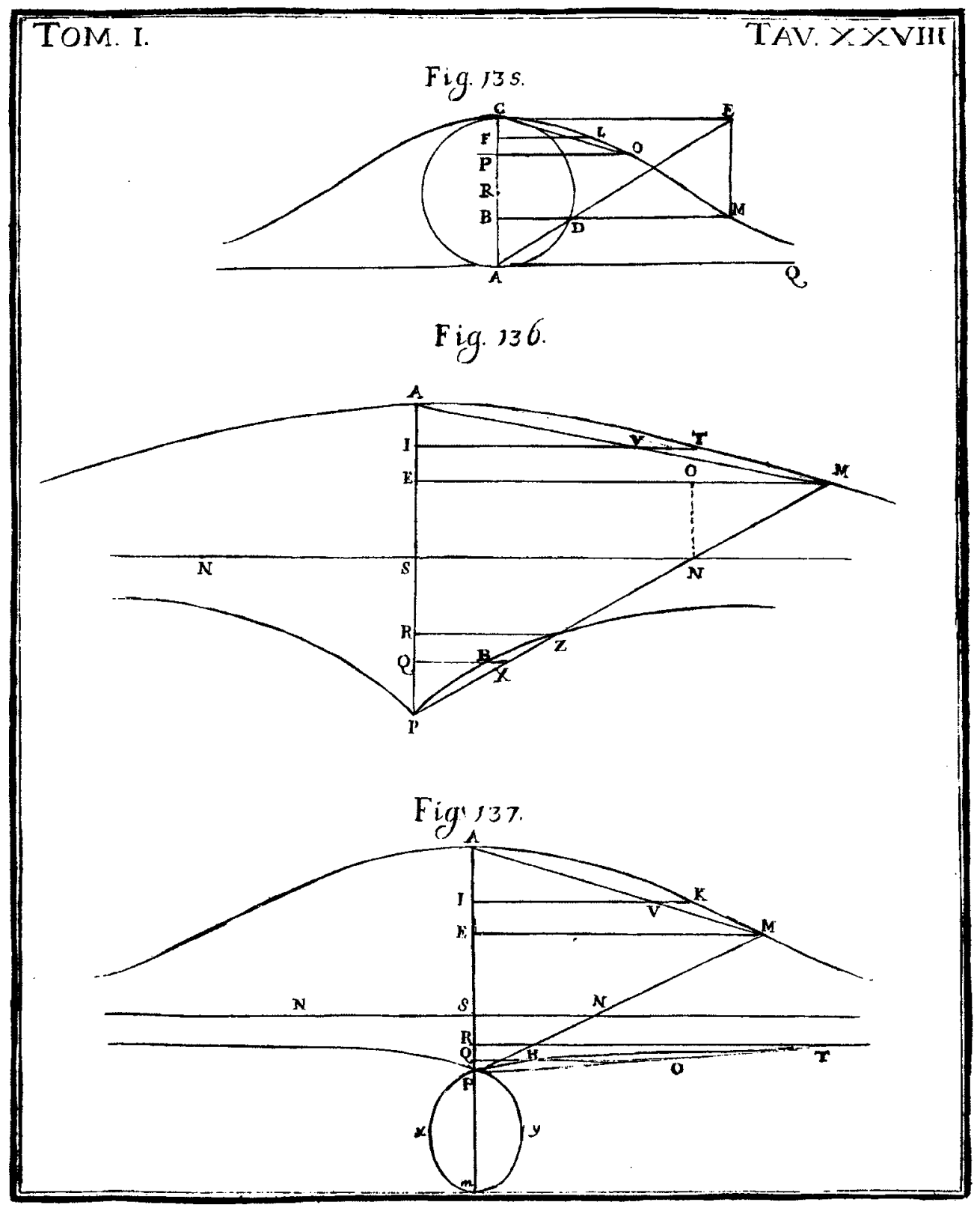

Fig. 4. Maria Gaetana Agnesi‘s versiera. Source: Maria Gaetana Agnesi, Instituzione analitiche ad uso della gioventù italiana (Milan 1748). Courtesy of Biblioteca Universitaria, Bologna. 
But there was more to Suardi's geometric pen than just one female curve. It also drew a rather fascinating byproduct of the cultural world of eighteenth-century mathematics known as "geometric flowers" (fig. 5). Invented by the Pisan mathematician Guido Grandi in 1728, who dedicated his own flowers to the Milanese countess Clelia Grillo Borromeo and named one curve the Cloelia in appreciation of her patronage, these figures look not unlike the results of our childhood spirograph designs - which is exactly what Soardi's elaborate machine was, since it placed wheels of different sizes in contact with each other to produce different curves (fig. 6). Grandi himself described the beauty of these curves as a seemingly infinite foliation of lines from a single center (Grandi 1728, 1, 41-76). ${ }^{19}$ They were mathematical forms worthy of female names, a two-dimensional world of complex points that evoked, in the minds of certain mathematicians, the three-dimensional world of curved flesh.

The more mathematically complex a figure became, the more female it seemed. This assumption, at least, seems quite clear in Suardi's New Instruments. Suardi placed his description of the geometric pen creating geometric flowers as the fourth of five shapes his pen could replicate: in order of progressive difficulty, that probably indicated the pedagogical plan of his mathematics instruction, his pen drew lines, circles, ellipses, geometric flowers, and finally cycloids such as Agnesi's versiera. By the time Suardi reached the description of geometric flowers, he was almost beside himself with excitement about the possibilities of this tool for facilitating his contact with scientific women. "I would place the Pen delineating these flowers solely in the hands of famous and learned Women," he declared (Suardi 1752, 113; emphasis added). He then suggested several candidates: Laura Bassi, Émilie du Chatelet, and of course Agnesi.

Suardi immediately assured his readership that he did not expect these specific women to come to Brescia to use his pen - far be it for him to presume that famous women philosophers would take instruction from a provincial mathematician. But he was surely hopeful that someone would draw geometric flowers with him. This was what he offered Medaglia Faini when she sought his instruction.

\section{Where did Suardi get his ideas?}

One source of information had very little to do with Italy and nothing to do with mathematics. It was cited, in French, in the notes to Suardi's New Instruments. Suardi had read and admired Fontenelle's Conversations - the very template for the sort of popular instruction of women he had in mind. At the end of several days of philosophical conversation, the lovely but initially rather ignorant Marquise shouts with joy: "I have the whole system of the universe in my head! I'm a scholar!" (Suardi

\footnotetext{
${ }^{19}$ This approach to mathematics found its general parallel in the popularization of many aspects of Newtonian and post-Newtonian science (see Mullin 1993; Sutton 1995).
} 


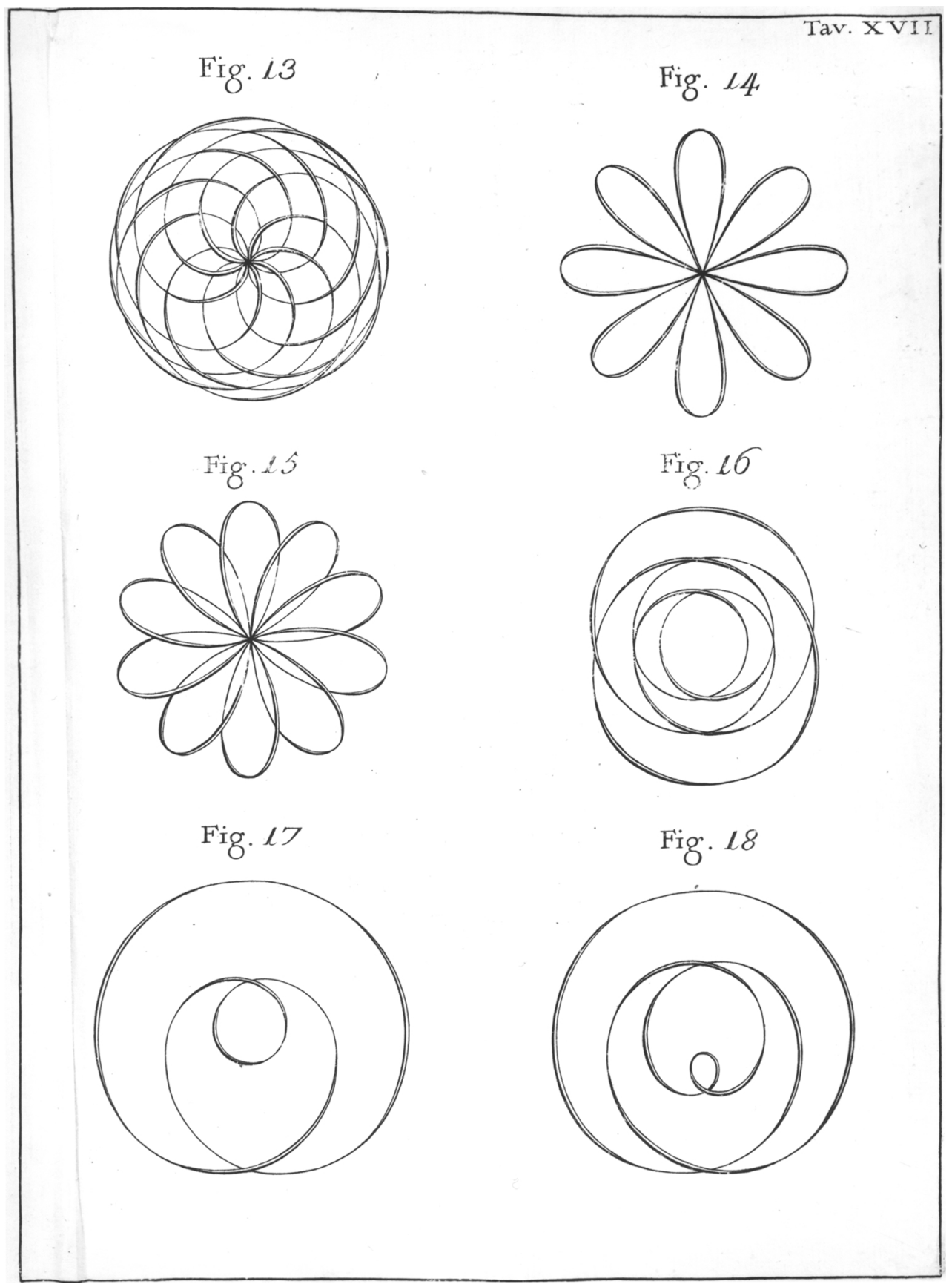

Fig. 5. Geometric flowers dedicated to Clelia Grillo Borromeo. Source: Guido Grandi, Flores geometrici ex Rhodonearum, et Cloeliarum Curvarum descriptione resultantes (Florence, 1728). Courtesy of the Biblioteca Comunale dell'Archiginnasio, Bologna. 


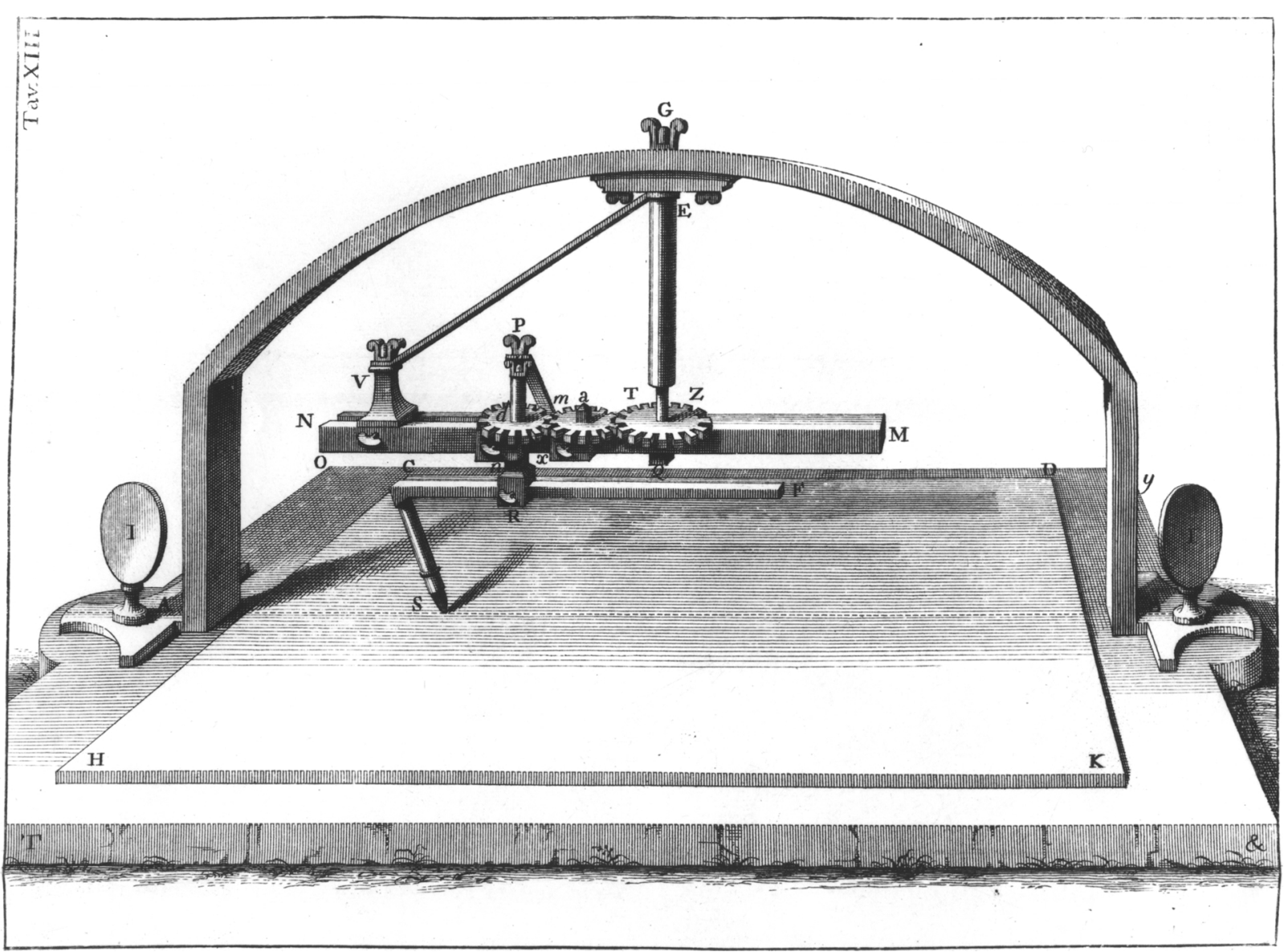

Fig. 6. Giambattista Suardi's geometric pen. Source: Giambattista Suardi, Nuovi istromenti per la descrizione di diverse curve antiche e moderne e di molte altre, che servir possono alla speculazione de' Geometrici, ed all'uso de' Practici (Brescia, 1752). Courtesy of the Biblioteca dell'Accademia dei Concordi, Rovigo. 
1752, 231; Fontenelle 1990, 73). Given the name of Suardi's villa, Fontanella, one wonders if he wasn't attempting to pattern his life after Fontenelle's own literary and scientific career in which the creation of a woman philosopher would be its ultimate fulfillment. ${ }^{20}$ True to the spirit of Fontenelle, he had initially considered writing his New Instruments in the form of a Latin dialogue and then had decided that it would better serve his audience as a vernacular treatise. ${ }^{21}$ The one letter of his that survives from the period in which he and Medaglia Faini knew each other discusses their efforts to perfect their use of the telescope. Suardi reported seeing a solar and lunar eclipse from his villa as well as his first observations of Jupiter's satellites and Saturn's rings "and the great lunar disk." "How noble and sublime is the work of astronomy!" he exclaimed. ${ }^{22}$ Fontenelle could not have done better in persuading a woman to look at the heavens.

It is also highly probable that Suardi read Algarotti's Newtonianism, for many of the same reasons as Medaglia Faini - and he was old enough to have read it in the first edition of 1737. Again, Suardi did not literally replicate the image of the male philosopher that he found in the pages of Fontenelle and Algarotti. He made important modifications to it by presenting himself as a successful instrument-maker, a purveyor of delightful tools that were utilitarian and pedagogical and, in some instances, designed specifically for the hand of a woman philosopher. If, as Algarotti had assumed, mathematics was too confusing and impenetrable for most women, Suardi had a partial solution to this problem: the geometric pen that helped them visualize the forms of mathematics with ease. Medaglia Faini was the woman in whose hand Suardi hoped to place the geometric pen so that they might trace the curve of Agnesi and experience the imaginary life of science sketched by Fontenelle and Algarotti (Brognoli 1785, 160). This, in fact, is what both of their eighteenthcentury biographers said about them, delighting in their reinvention of a literary relationship.

Provincial scientific life in the eighteenth century was indeed a world of possibilities, in which many people aspired to philosophize, if not actually become natural philosophers, as a product of reading and conversing about knowledge. Yet it is striking, to my mind, how the reenactment of Fontenelle and Algarotti in Salò reveals the limits of a literary persona. On the one hand, Suardi had greater expectations of his female pupil than his fictional counterparts, neither of whom deigned to teach mathematics to women. His image of the woman philosopher lay somewhere between the fictional Marchesa and the accomplishments of Agnesi. On

\footnotetext{
${ }^{20}$ As Marta Cavazza reminded me, "Fontana" and "Fontanella" were common names for Italian villas so it may be pure coincidence and readers shouldn't make too much of the Fontanella/Fontenelle analogy. But please excuse a historian for enjoying the possibilities, especially with a man who married a woman named "Countess Curves."

${ }^{21}$ Biblioteca Civica Queriniana, Brescia, ms. K. V. 49 (Guzzaga, Memoria, n.4, ff. 9, 21).

${ }^{22}$ Biblioteca Comunale, Forlì, Autografi Piancastelli (Suardi to Petronio Mateucci, Brescia, 10 November 1762). I am still hoping to find further materials relating to his life in the Archivio di Stato, Brescia.
} 
the other hand, his complex relationship to the idea of the woman philosopher imposed well-defined limits on the nature and purpose of Medaglia Faini's education, which was more for his own fulfillment than for hers. The mathematics that Suardi offered her was not the calculus taught in the universities or debated in scientific academies. It was the poetic calculus of Arcadia that made mathematics as pleasurable, witty, and trivial as the poetry Medaglia Faini despised. It was a mathematics, in other words, fitted to the mind of a woman by resembling her body through its curves a Cloelia more than a versiera. ${ }^{23}$ And even this kind of mathematics was accessible to only a handful of women. "Few women," wrote her biographer Antonio Brognoli in 1785, "will be able to manage this pen and to embellish these flowers that are not found in the modern toilette" (ibid.). ${ }^{24}$

The limits of Diamante Medaglia Faini's aspirations to become a mathematician, and her distance from the world of Laura Bassi are quite striking, even if they both intersected through the pages of Algarotti. Bassi had the resources of Bologna's university and academies at her disposal, and created a position for herself in the republic of letters that allowed her to participate fully in discussions about natural knowledge. Medaglia Faini had only Suardi and his geometric pen at her disposal and this indeed constrained what she was able to accomplish in a small town like Salò. She took her science were she found it while dreaming of something far more ambitious than she herself was able to accomplish (or than her tutor Suardi probably had in mind). Even Cristina Roccati's physics lectures in Rovigo, which were filled with exhortations to her male and female listeners to see mathematics as a necessary if difficult foundation for natural philosophy, would have taught her more than this about science.

Medaglia Faini's second career as she called it, carved in the writings of Fontenelle and Algarotti and molded in the hands of her tutor Suardi, epitomizes the tragedy of unfulfilled ambition. Yet if it were only defined by these ingredients, it would be far less interesting than it actually is. Instead we should see her response to the accomplishments of women such as Bassi, Agnesi, and Roccati - who, to differing degrees, published, taught, and engaged with the learned scientific world - as, in itself, a sort of success. The possibility of becoming a woman philosopher existed in singular instances. Medaglia Faini was among the first to ask how it might become a possibility for all women. She understood how the publicity accorded to a handful of women philosophers had begun to transform the image of knowledge in the mideighteenth century and responded to these results by formulating her own aspirations in relationship to their accomplishments. In her instance, the effort and the idea that it engendered - that all women were capable of scientific knowledge - was more important than the result.

\footnotetext{
${ }^{23}$ For further discussion of the embodiment of gender in the community of Italian natural philosophers, see Findlen 2003.

${ }^{24}$ Toletta is a word that Algarotti introduced into print in Italy, quite controversially in the eyes of his critics, with the publication of Newtonianism for Ladies.
} 
Medaglia Faini's inability to fulfill her intellectual desires not only reflected the problems of pursuing science in the provinces but also suggests how the changing climate for women philosophers in general in the second half of the eighteenth century became a limiting factor for women with her ambitions (Schiebinger 1989, 66-277). The emerging division between scientific popularization and science proper reflected renewed skepticism about the idea of the woman philosopher. Authors of educational treatises such as Melani already indicated their doubts in the 1750s when they argued, anticipating the famous words of Rousseau, that women had different intellectual needs and therefore deserved their own library of books written specifically per le donne. The kind of mathematics for women that Suardi offered Medaglia Faini helped to separate what she should learn from what he himself had mastered, just as Algarotti previously had done in his presentation of Newton's optics. This new sense of the gender of knowledge had important consequences for the participation of women in science. By the $1770 \mathrm{~s}$, public criticism of learned women replaced the earlier praise that had launched such careers as Laura Bassi's. Critics talked of a "female way of thinking" and a "female metaphysics" that prevented women from understanding the sciences, as creatures dominated by passion rather than reason (Zecchini 1771, 23; Cavazza 2003). By 1777, when the anonymous Philosophy for Ladies appeared in Venice, the woman mathematician was an object of ridicule. "Mathematics. . . will bore you in all respects with its long demonstrations and infinite calculations," declared its author to his female readers. "Moreover, it would be improper to present it right away to a young Lady" (Anon. 1777, 1:7).

Shortly after Faini's death, women ceased to enjoy degrees and professorships in Italy, as they had done during the preceding century. The boundaries, it seems, had hardened. In the midst of this transformation, Faini may strike us as a voice in the wilderness, a failed mathematician in the hands of a second-rate Fontenelle. Yet it is precisely such people who often tell us what we most need to understand. In the middle of the eighteenth century, the idea of becoming a scientist existed for ambitious women and there were a number of models upon which to draw, real and imaginary. But the practice of science and the cultural environment in which it flourished presented formidable obstacles to the realization of this endeavor. By the 1770s, the heady atmosphere of the 1730s, when Laura Bassi was acclaimed the greatest woman philosopher since Hypatia and Algarotti immortalized her in print, had long since vanished. Women continued to need science, but science no longer needed women to indicate its visibility and diffusion in society.

\section{References}

Agnesi, Maria Gaetana. 1748. Instituzione analitiche ad uso della gioventù italiana. Milan.

Algarotti, Francesco. 1757. Opere varie del Conte Francesco Algarotti. Venice.

Algarotti, Francesco. 1791-94. Opere. 17 vols. Venice.

Algarotti, Francesco. [1969] 1977. Dialogo sopra l'ottica neutoniana. Edited by Ettore Bonora. Turin:

Einaudi. 
Anon. 1777. La filosofia per le dame. 2 vols. Venice.

Anon. 1789. "Riflessioni sopra le Donne e sopra l'utilità che potrebbero ricavare dal coltivare le lettere." Giornale scientifico, letterario e delle arti. Tome 2, part 2: 219-220.

Arato, Franco. 1991. Il secolo delle cose. Scienza e storia in Francesco Algarotti. Genoa: Marietti.

Becelli, Giulio Cesare. 1738. Trattato nuovo della divisione degli ingegni secondo la vita attiva e contemplativa, scritto singolarmente ad uso della nobiltà d'Italia. Verona.

Berti Logan, Gabriella. 1994. "The Desire to Contribute: An Eighteenth-Century Italian Woman of Science." American Historical Review 99:785-812.

Biagioli, Mario. 1993. Galileo, Courtier: The Practice of Science in an Age of Absolutism. Chicago: University of Chicago Press.

Brognoli, Antonio. 1785. Elogi di bresciani per doctrina eccellenti del secolo XVIII. Brescia.

Bustico, Guido. 1913. "Le accademie di Salò.” Ateneo veneto vol. 36, n. 2: 129-168.

Bustico, Guido. 1929. "Diamante Medaglia Faini.” Brescia (December): n. p.

Cataneo, Giovanni de. 1753. Il filosofismo delle belle. Venice.

Cavazza, Marta. 1990. Settecento inquieto. Alle origini dell'Istituto delle Scienze di Bologna. Bologna: Il Mulino.

Cavazza, Marta. 2003. "Woman's Dialectics, or the Thinking Uterus: An Eighteenth-Century Controversy on Gender and Education." In Nature Embodied, edited by Gianna Pomata and Lorraine J. Daston. Berlin: Verlag.

Ceranski, Beate. 1996. "Und sie fürchtet sich vor niemandem”: Die Physikerin Laura Bassi (1711-1778). Frankfurt: Campus.

Ebranati, Mario. 1989. "Diamante Medaglia.” In Donne illustri sul Garda, 95-97. Brescia: Edizioni di Storia Bresciana.

Ehrman, Esther. 1986. Mme du Châtelet: Scientist, Philosopher, and Feminist of the Enlightenment. Leamington Spa, U. K.: Berg.

Ferrone, Vincenzo. 1995. The Intellectual Roots of the Italian Enlightenment: Newtonian Science, Religion, and Politics in the Early Eighteenth Century. Translated by Sue Brotherton. Atlantic Highlands, NJ: Humanities Press.

Findlen, Paula. 1993. "Science as Career in Enlightenment Italy: The Strategies of Laura Bassi (1711-78)." Isis 84:441-469.

Findlen, Paula. 1995. "Translating the New Science: Women and the Circulation of Knowledge in Enlightenment Italy." Configurations 2:167-206.

Findlen, Paula. 1999. "A Forgotten Newtonian: Women and Science in the Italian Provinces." In The Sciences in Enlightened Europe, edited by William Clark, Jan Golinski, and Simon Schaffer, 313-349. Chicago: University of Chicago Press.

Findlen, Paula. 2003. "The Scientist's Body: The Nature of a Woman Philosopher in Enlightenment Italy." In Nature Embodied, edited by Gianna Pomata and Lorraine J. Daston. Berlin: Verlag.

Findlen, Paula. Forthcoming. Women Who Understood Newton: Laura Bassi and Her World. New York: Knopf.

Fontenelle, Bernard le Bovier de. 1990. Conversations on the Plurality of Worlds. Translated by H. A. Hargreaves. Berkeley: University of California Press.

Grandi, Guido. 1728. Flores geometrici ex Rhodonearum, et Cloeliarum Curvarum descriptione resultantes. Florence.

Graziosi, Elizabetta. 1992. “Arcadia femminile: presenze e modelli.” Filologia e critica 17:321-358.

Harth, Erica. 1992. Cartesian Women: Versions and Subversions of Rational Discourse in the Old Regime. Ithaca: Cornell University Press.

Lougee, Carolyn. 1976. Le Paradis des femmes: Women, Salons and Social Stratification in Seventeenth-Century France. Princeton: Princeton University Press.

Maugain, Gabriel. 1923. "Fontenelle et l'Italie." Revue de littérature comparée 3:541-603.

Mazzoti, Massimo. 2001. "Maria Gaetana Agnesi: The Unusual Life and Mathematical Work of an Eighteenth-Century Woman.” Isis 92:657-683. 
Medaglia Faini, Diamante. 1774. Versi e prose di Diamante Medaglia Faini. Edited by Giuseppe Pontara. Salò.

Melani, Enea Gaetano. 1757. (Publishing under the pseud. "Ereste Eleucanteo"). Il libro per le donne. Venice.

Melli, Elio. 1960. Epistolario di Laura Bassi Veratti. In Studi e inediti per il primo centenario dell'Istituto Magistrale Laura Bassi. Bologna: STEB.

Messbarger, Rebecca. 2002. The Century of Women: Representations of Women in Eighteenth-Century Italian Public Discourse. Toronto: University of Toronto Press.

Messbarger, Rebecca, and Paula Findlen with Rachel Scarlett-Trotter. Forthcoming. The Contest for Knowledge: Debates about Women's Education in Eighteenth-Century Italy.

Mullin, John. 1993. "Gendered Knowledge, Gendered Minds: Women and Newtonianism, 1690-1760." In A Question of Identity: Women, Science and Literature, edited by Marina Benjamin, 41-58. New Jersey: Rutgers University Press.

Pasero, Carlo. 1969. "L'Ateneo di Salò - Quattro secoli di vita accademica." In Il Lago di Garda. Storia di una communità lacuale. Salò: Ateneo di Salò. Vol. 1, 43-84.

Pfieffer, Jeanne. 1991. "La littérature scientifique pour les femmes au siècle des Lumières." In Sexe et genre. De la hiérarchie entre les sexes, edited by Marie-Claude Hurtig, Michèle Kail and Hélène Rouch, 137-146. Paris: Éditions du Centre National de la Recherche Scientifique.

Pluche, Noel de la. 1741-82. Spectacle de la Nature. 8 vols. Paris.

Pontara, Giuseppe. 1774. "Vita di Diamante Medaglia Faini." In Versi e prose, by Diamante Medaglia Faini, i-xix. Salò.

Roche, Daniel. 1978. Le siècle des Lumières en province: académies et académiciens provinciaux, 1680-1789. 2 vols. Paris: Mouton.

Schiebinger, Londa. 1989. The Mind Has No Sex? Women in the Origins of Modern Science. Cambridge, MA: Harvard University Press.

Soppelsa, Maria Laura, and Eva Viani. 1999. "Dal newtonianismo per le dame al newtonianismo delle dame. Cristina Roccati una 'savante' del Settecento Veneto." In Donne, filosofia e cultura nel Seicento, edited by Pina Totaro, 211-240. Rome: Consiglio Nazionale delle Ricerche.

Suardi, Giovan Battista. 1752. Nuovi istromenti per la descrizione di diverse curve antiche e moderne e di molte altre, che servir possono alla speculazione de' Geometrici, ed all'uso de' Practici. Brescia.

Suardi, Giovan Battista. 1764. Trattenimenti matematici del Conte Giambattista Suardi Bresciano dell'Accademia dell'Istituto e Clementina di Bologna e degli Agiati di Roveredo. Brescia.

Succi, Carlo. 1992. "Un matematico bresciano: Ramiro Rampinelli monaco olivetano (1697-1759)." Rodegno: Centro storico olivetano. Supplement to Commentari Ateneo di Brescia.

Sutton, Geoffrey. 1995. Science for a Polite Society: Gender, Culture, and the Demonstration of Enlightenment. Boulder, CO: Westview Press.

Terrall, Mary. 2000. "Natural Philosophy for Fashionable Readers." In Books and the Sciences in History, edited by Marina Frasca-Spada and Nick Jardine, 239-254. Cambridge, U. K.: Cambridge University Press.

Torriceni, Francesco. 1760. "De vita Ramiri Rampinelli Epistola.” In Lectiones opticae, by Ramiro Rampinelli, xi-xxxi. Brescia.

Truesdall, Clifford. 1992. "Corrections and Additions for Maria Gaetana Agnesi." Archive for the History of the Exact Sciences 43:385-386.

Zan, Mauro De. 1981. "La messa all'Indice del Newtonianismo per le dame di Franceso Algarotti." In Scienza e letteratura nella cultura italiana del Settecento, edited by Renzo Cremante e Walter Tega, 133-147. Bologna: Il Mulino.

Zecchini, Petronio. 1771. Di geniali. Della dialettica delle donne. Bologna. 
